\title{
Is there a Need to Conduct Water Rights Transactions in the Water-rich Areas of China?A Case Study of the Taihu Basin
}

\author{
Fengping $\mathrm{Wu}^{1}$, Min $\mathrm{Zhu}^{1, *}$, Shang $\mathrm{Luo}^{2}$, Junyuan Shen ${ }^{1}, \mathrm{Xia} \mathrm{Xu}{ }^{1}$, Fang $\mathrm{Li}^{1}$ \\ 1School of business, Hohai University, Nanjing 211100, China. \\ 2 Botian Environment group co. LTD, Beijing 100000, China. \\ *minzhu@hhu.edu.cn; Tel.: +86-17705184635
}

\begin{abstract}
To alleviate the contradiction between the increasing demand for water and the shortage of resources and to provide a favorable institutional environment for water rights trading, the Chinese government has strengthened the top-level design of water management system. However, the water-rich regions (southern regions of China) have good water resource endowment and a surplus of total water consumption indicators. Does this mean that there is no incentive and no need to conduct water rights trading in these regions? Through the investigation of water rights circulation cases in the Taihu Basin, a typical water-rich region of China, we established the existence of trading demand and some difficulties in conducting transactions. This paper argues that the needs of trading include alleviating the water gap in regional development, solving the water demand for large new projects, coordinating trans-jurisdiction water disputes. The plight of trading includes the lack of awareness, irregular process, excessive administrative intervention, and imperfect trading system.
\end{abstract}

Keywords: water-rich area; water rights transaction; trading need; Taihu Basin

\section{Introduction}

Water rights trading is one of the effective ways to optimize the uneven spatial and temporal distribution of water resources and improve the efficiency of water allocation ${ }^{[1-3]}$. To alleviate the contradiction between the increasing demand for water in regional economic development and the shortage of water resources, the Chinese government has continuously strengthened the top-level design of water rights management system ${ }^{[4-6]}$, providing a favorable institutional environment for the development of water rights trading ${ }^{[7]}$. Since the beginning of the 21 st century, the Ministry of Water Resources has issued a series of normative documents and departmental regulations on water rights management ${ }^{[8]}$. Some of the key documents issued are "The Guidance on Water Rights Conversion Pilot on the Yellow River Trunk Stream between the Inner Mongolia Autonomous Region and the Ningxia Hui Autonomous Region by the Ministry of Water Resources" (2004), "Several Opinions on Water Rights Transfer by the Ministry of Water Resources" (2005), "The Framework of Water Rights System Construction"' (2005), "The Interim Management Measures of Water Rights Transaction" (2016), and "The Guidance on Enhancing Water Use Manners Control" (2016). In addition, the Ministry has carried out many pilot projects on the nationwide reform of the water rights management system. For example, the water rights conversion pilot ${ }^{[9]}$ was carried out along the Yellow River in the Qingtongxia irrigation area of Ningxia autonomous region and the south bank irrigation region of Inner Mongolia autonomous region in 2003 to explore the transfer of surplus agricultural water rights to the industrial stakeholders by investing in the construction of water-saving projects. Various other types of water rights trading pilot projects were implemented in 2014, including water rights confirmation registration, water rights trading, and water rights management system construction. In 2015, The Chinese government proposed the establishment and improvement of the initial allocation system and the trading market of water rights. China's first state-level water rights trading platform was established in 2016; it implemented regional water rights trading, water access rights trading, and irrigation users' water rights trading.

China's water rights trading is mainly concentrated in the north water shortage areas ${ }^{[10]}$, such as the water ticket trading in Zhangye city, the water rights transfer between the industry and the agriculture in Inner Mongolia province, and the water transfer of cross-province at the upstream of the Zhanghe River. Some trading is distributed in the abundant water area in the south of China ${ }^{[11]}$, such as the permanent water rights transaction between Dongyang city and Yiwu city and the water rights transfer between Yuyao city and Cixi city. Compared to the water-deficient regions in 
the north of China, the regional total indicator of water use is surplus in the water-rich regions, and the contradiction between the water demand and water shortage in economic development is still unknown. Therefore, the motivation to conduct water rights trading is lower than that in the north. Furthermore, in the virtual water trade, the southern water-rich region imports the virtual water, but the northern water-deficient region exports the virtual water ${ }^{[12]}$. The cost of food production in water-rich areas is more expensive than in water-scarce areas ${ }^{[13]}$. Does this mean that China's national water rights management system reform is inconsistent with the actual demand of the water-rich areas, and these regions are passive in conducting the water rights trading pilot? Is there an incentive or need to implement water rights trading in these places?

Through the investigation of water rights circulation cases in the Taihu watershed, a typical water-rich region of China, we discovered the demands of water rights trading with regional characteristic and some difficulties in conducting transactions.

\section{Materials and Methods}

\subsection{Study Area and Data Sources}

The Taihu Basin ${ }^{[14]}$ covers the Taihu Basin itself along with the southeastern river basins (figure 1), located in the southeast coastal area of China. It is a region of rapid economic development. The Taihu Basin covers most areas in south Jiangsu province, the mainland part of Shanghai, Zhejiang province, Fujian province (except the Hanjiang River Basin), Huangshan mountain in Anhui province, and some areas in Xuancheng city, with a total area of $245,000 \mathrm{~km}^{2}$. The per capita GDP of the Taihu Basin is 95,000 yuan and it contributes $18.1 \%$ of the annual GDP of China. The average annual precipitation of the Taihu Basin is over 2,000 mm, and the available water resources are abundant. In $2016,71.8 \%$ of the evaluated river water quality reached or exceeded category III, and 354 of the 611 water functional zones met the standard, reaching the standard rate of $57.9 \%$.

Some of the data in this paper comes from field research, and some from the Taihu Basin authority at the Ministry of Water Resources (2016).

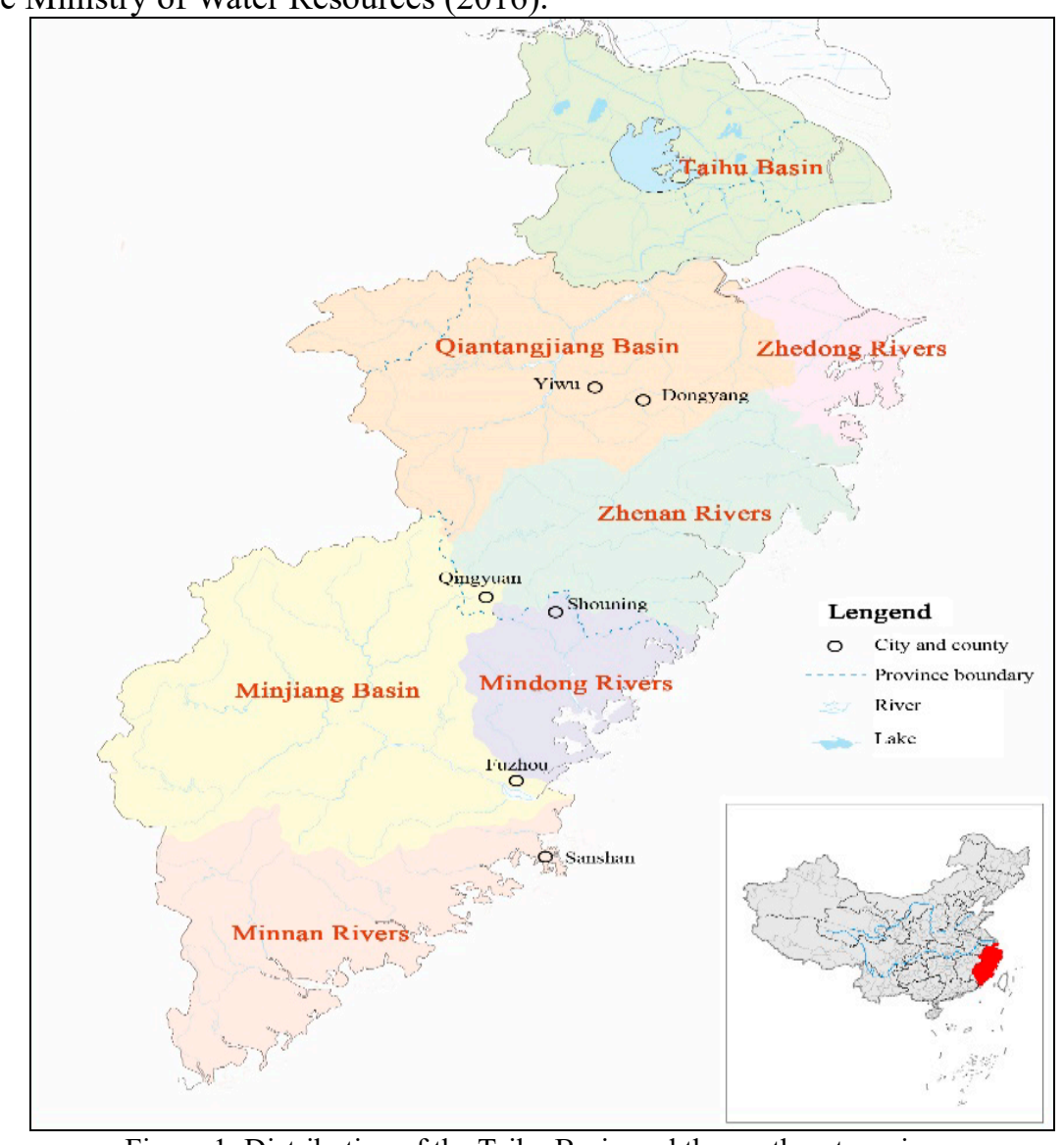

Figure 1: Distribution of the Taihu Basin and the southeastern rivers

\section{Case Analysis of Water Rights Trading in the Taihu Basin}

Through the investigation, we found that with the rapid social and economic development in 
the water-rich areas, some water rights trading cases took place in the Taihu Basin, particularly in relatively scattered regions located in Zhejiang province, Fujian province, and on the border of the provinces. These trading cases carry obvious regional characteristics.

\subsection{Water Rights Transfer between Dongyang City and Yiwu City}

\subsubsection{Case Description}

The two cities were adjacent to the upper reaches of the Jinhua River, an important tributary of the Qiantang River. Dongyang city had 1.608 billion $\mathrm{m}^{3}$ of available water resource and per capita of water was $2,126 \mathrm{~m}^{3}$. It had several rivers and streams and two large reservoirs (Hengjin reservoir and Nanjiang reservoir) under its jurisdiction. The total amount of water resources in Yiwu city was 719 million $\mathrm{m}^{3}$, and the per capita of water was $1,130 \mathrm{~m}^{3}$, which was far lower than the national average per capita of water $\left(2,292 \mathrm{~m}^{3} /\right.$ person). The lack of water conservancy infrastructures within the jurisdiction area was also noted.

The two cities were geographically close to each other, but the gap in their economic development level was quite large. The per capita GDP of Yiwu city reached 17,945 yuan in 2000, but the shortage of water restricted its economic development. Dongyang city had abundance of water, but it registered a lack of capital for development. To alleviate the temporary water shortage crisis in Yiwu city, Dongyang had provided over 2 million $\mathrm{m}^{3}$ of high-quality water resources to Yiwu city twice before 2000 .

To solve the water shortage in the economic development of Yiwu city and the scarcity of financial funds of Dongyang city, the two sides reached an agreement on water rights transfer on November 24, 2000. According to the agreement ${ }^{[15]}$, Yiwu city invested a one-time sum of 200 million yuan to purchase the right to use the $49,999,000 \mathrm{~m}^{3} /$ year water volume of Hengjin reservoir in Dongyang city (executed China's standards for class 1 drinking water) and was responsible for planning and funding the construction of the diversion pipeline project.

\subsubsection{Case Commentary}

It set a precedent for water rights trading in China. The main parties of the water transaction were the government of Dongyang city (transferor) and the government of Yiwu city (transferee). The trading object was the permanent right to use 49,9 million $\mathrm{m}^{3}$ water annually in Hengjin reservoir.

After the water rights trading between Dongyang city and Yiwu city, other regions in China had carried out practical exploration of water rights transactions. For example, the ministry of water resources had carried out pilot water rights conversion in the Yellow River basin. However, China's water rights trading practice started late and has not shaped a mature water rights trading market. It exposed many problems in water rights trading management, such as water regulatory issues. Therefore, the government was rushed to publish the water rights management system regulatory documents and departmental regulations.

The trade took 10 years to develop from temporary water administrative coordination to permanent water rights trading. During the negotiation of trading price and management mechanism, local governments at all levels have played a good role in basic regulation and control and promoted the conclusion of water rights trading intention.

3.2 Water Compensation Agreements across Provincial Borders

\subsubsection{Case Description}

At the end of 2000 year, the Dayankeng hydropower station was built at the tributary of the Nanyang stream of the Oujiang River basin by Qingyuan County in Zhejiang province. The water needed to generate electricity was diverted across the nearby river basin through the diversion tunnel with a water diversion area of $78 \mathrm{~km}^{2}$ (figure 2). The construction of the diversion tunnel at the upper reaches of the Toxi stream (the border river between the Zhejiang province and the Fujian province) sparked opposition by Shouning County in Fujian province. Shouning County in Fujian province was located at the lower reaches of the Toxi stream. It argued that the diversion of cross-basin in the upper reaches would have adverse effects on the industrial, habitable, and ecological environment of the lower reaches and asked to stop the construction of water diversion projects. These requirements were rejected by the Zhejiang province because the upstream of the Toxi was under its jurisdiction and the area of diversion occupied only $29 \mathrm{~km}^{2}$, which would not affect the water safety of the lower reaches. Therefore, the two sides generated a water dispute of cross-provincial jurisdiction, which hindered the operation of the hydropower station. The accurate location of trading area is shown in Figure 2. 


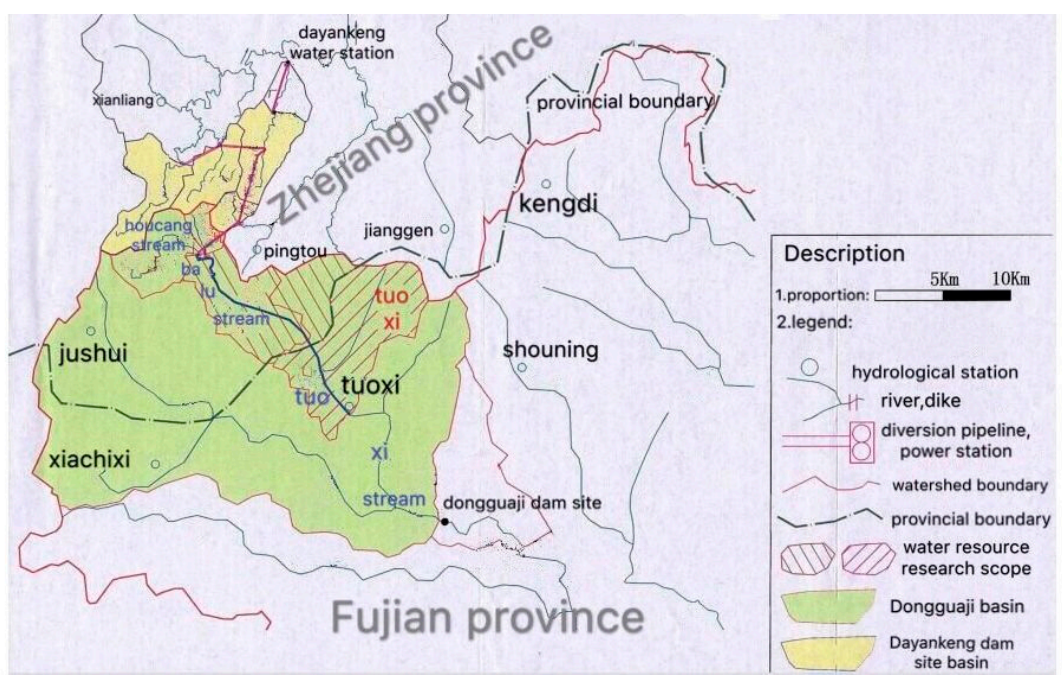

Figure 2. The location of trading area

It was difficult to coordinate water disputes across provincial administrative jurisdiction which continued for three years until 2003. Under the coordination of the Taihu Basin authority of the Ministry of Water Resources of China, the two sides reached a cross-basin water compensation agreement and successfully resolved the dispute of cross-basin water diversion. According to the agreement, the upper limit of water diversion capacity was 26.22 million $\mathrm{m}^{3}$ annually from the upper reaches of the Toxi river basin by the Dayankeng hydropower station; Shouning County built a reservoir (capacity about 1 million $\mathrm{m}^{3}$ ) at the lower reaches of Toxi river basin. The Dayankeng hydropower station paid 3 million yuan for the construction of reservoir. To subsidize the infrastructure construction in less developed regions, Shouning County applied for 4 million yuan from the Chinese government with the assistance of Zhejiang government.

\subsubsection{Case Commentary}

The development of water resources in the inter-provincial boundary area is a sensitive issue. Water resource development projects in border areas should be well-investigated and carefully planned to assess their environmental impact. Additionally, the prevention and consultation mechanism for water disputes should be established to minimize the impact of possible water disputes on water resources development.

The diversion of across the basin by Dayankeng hydropower station transferred some water rights in the Toxi River. After several consultations that went on for three years, the two provinces formed a compensation agreement to resolve the water dispute, which was essentially a regional water rights transaction between the upstream and downstream sections of the river. The transferee of trade was Shouning County in Fujian province, and the transferee is Qingyuan County in Zhejiang province.

In the compensation agreement, the basin eco-environmental water amount of the Toxi River was determined to be $90 \%$ according to "the technical rules of the national comprehensive planning for water resources (trial)." The provincial section flow was $0.14 \mathrm{~m}^{3} / \mathrm{s}$ and the township section discharge was $0.30 \mathrm{~m}^{3} / \mathrm{s}$, which served as the standard water flow for the Toxi River basin eco-environment. The total amount of the allocated water did not exceed the utilization rate of the river itself which is $40 \%$.The amount of water transferred did not exceed $20 \%$ of the total amount of the river. The measurement of the tradable water amount in the Toxi stream provided a reference for determining the tradable water amount in water-rich areas.

\subsection{The Acquisition of the Beilin Reservoir by Fuqing Nuclear Power Co., Ltd.}

\subsubsection{Case Description}

Fuqing Nuclear Power Co., Ltd. of China Nuclear Power Group (hereinafter referred to as 'Fuqing Nuclear Power') was established on May 16, 2006, with a total investment of nearly 100 billion yuan. To ensure the safe operation of nuclear power equipment, Fuqing Nuclear Power and the government of Sanshan town of Fuqing city (hereinafter referred to as 'Sanshan town government') signed the purchase agreement to obtain the permanent right to use the water resources of the Beilin reservoir at a cost of approximately 20.341 million yuan. The management right of the reservoir was transferred to the Fuqing Nuclear Power. The specific cost structure of 
the purchase agreement is shown in Table 1. The purchase agreement stipulated that Fuqing Nuclear Power should not affect the agricultural, production, and living water of the residents around the reservoir. The Beilin reservoir retained the agricultural irrigation function and provided residential water for the local people. The total amount of water from the reservoir used by Fuqing Nuclear Power should not exceed 2.3 million $\mathrm{m}^{3}$.

Table 1. The cost structure of purchase agreement of the Beilin Reservoir

\begin{tabular}{ccc}
\hline Number & Item & Amount (ten thousand yuan) \\
\hline 1 & Land requisition & 706.00 \\
2 & Agricultural land occupation & 21.89 \\
3 & The investment of reservoir construction & 385.53 \\
4 & Maintenance costs & 187.90 \\
5 & Re-housing expenses (school) & 198.00 \\
6 & Matching funds of re-housing & 304.55 \\
7 & Agricultural tax compensation over the years & 170.25 \\
8 & Follow-up spillway 200 m requisition and construction costs & 60.00 \\
& Remit total & 2034.12 \\
\hline
\end{tabular}

\subsubsection{Case Commentary}

In this case, the agreement was not a simple water right trade, and it includes the transfer of reservoir's management right and the water use right. The transfer party is the Sanshan town government and the transferee is Fuqing Nuclear Power. The term is a permanent water rights transaction and the transaction price is 20.341 million yuan. Certainly this was a typical way of using market means to solve the new water demand of large, newly-built enterprises; this deal also provided a price reference for the trading of the reservoir.

The water used for production and residential purposes in the area depends on the water source of the reservoir, and the local provisions were made in the third part of the deal. In the agreement, it was clear that the plant should freely provide water for the surrounding residents for non-profit use because the construction of the reservoir was performed by the local people and they are partial owners of the property. This was undoubtedly the factor that minimized the third-party impact of the transaction. The settlement of the transaction's impact on the third party provides a reference for the water rights trade of small reservoirs in water-rich areas.

\subsection{Water Rights System Reform in Quanzhou City}

\subsubsection{Case Description}

The Jinjiang River runs through the administrative jurisdiction of Quanzhou city. Its upper reaches were mountainous areas with abundant water resources, while the lower reaches were coastal areas with rapid economic development and a lack of water resources. To coordinate the water resource demand for the social and economic development of each county (city, district) in the basin, Quanzhou city formulated the water distribution scheme for the downstream of Jinji clough in the Jinjiang River in 1996, and the water resources below the Jinji clough of the Jinjiang River were distributed to each county (city, district) in proportion. Based on the water distribution scheme for the Jinji clough downstream of Quanzhou city, Quanzhou established the investment allocation system for water conservancy projects, which solved the financing problems of many water conservancy projects.

In 2008, to coordinate the water demand diversity of various counties (city, area), Quanzhou released "Quanzhou Configuration of Water Resources Scheduling Management Regulations". It stipulated that the exceed use of water beyond the annual plan of water dispatching program should get the water indicators under the principles of water right transfer and pay the compensation for the water rights index. The department of water administration of Quanzhou city should compensate the water rights licensor; water rights transfer across the river basins, counties (cities, districts), and projects could be carried out in each administrative region if the amount of water exceeds or saves the quota. In 2010, Quanzhou city adjusted the proportion of water distribution according to regional economic development demand and administrative division.

In 2014, to solve the problem of water resource shortage in coastal areas and optimize the allocation of reservoir resources within the jurisdiction area, Quanzhou implemented the "Seven Reservoir Connectivity Project". However, the Pengcun reservoir project had the potential to 
affect the water safety of Yongtai county, Fuzhou city, which caused a water dispute across the municipal jurisdiction. According to "Quanzhou Water Resources Allocation and Dispatch Management Regulation", Quanzhou municipal government and Fuzhou municipal government signed a water transfer compensation agreement and thus resolved the water dispute. The agreement stipulated that Quanzhou should pay a compensation of RMB 19.26 million yuan to Yongtai county; the Pengcun reservoir could reduce the releasing volume of 50 million $\mathrm{m}^{3}$ per year to the downstream of Dazhangxi stream in Yongtai county, Fuzhou city.

\subsubsection{Case Commentary}

Relying on the water distribution scheme, the water rights management system was established in Quanzhou city. Based on the water distribution proportion of each county (city, district) set in the water distribution scheme for the downstream of the Jinjiang River, Quanzhou had formulated water rights management systems such as water resource allocation and dispatch management regulations and capital allocation system. These had strengthened the comprehensive utilization and regulation of water resources in the Jinjiang River Basin. The relevant water rights management system also provided the system basis and reference for coordinating the construction and financing of major water conservancy projects in each county (city and district) of the basin, as well as the settlement of water disputes across municipal administrative jurisdiction.

Obviously, the water rights management system reform of Quanzhou achieved a good result. However, the success of the water rights management system reform was highly related to the fact that the government of Quanzhou was the highest management authority in the Jinjiang River watershed. This relationship of administrative jurisdiction reduced the difficulty and the cost of administrative coordination in implementing the water management system.

\section{Result and Discussion}

\subsection{A Summary of Trading in Water-rich Regions}

It was clear that water rights deals needed to be carried out in water-rich areas to address different practical needs and optimize the allocation of water resources ${ }^{[16]}$. The summary of trading in water-rich regions is shown in the Table 2.

Table 2: A summary of trading in water-rich regions

\begin{tabular}{|c|c|c|c|c|c|c|}
\hline $\begin{array}{l}\text { Vitem } \\
\text { Numbex }\end{array}$ & Year & Main parties & Objective & Region & Deadline & Form \\
\hline 1 & 2000 & $\begin{array}{l}\text { Dongyang city, } \\
\text { Yiwu city }\end{array}$ & $\begin{array}{c}\text { solve water } \\
\text { demand }\end{array}$ & $\begin{array}{l}\text { under provincial } \\
\text { jurisdiction }\end{array}$ & permanent & $\begin{array}{c}\text { government to } \\
\text { government }\end{array}$ \\
\hline 2 & 2003 & $\begin{array}{l}\text { Dayankeng } \\
\text { Hydro Station, } \\
\text { Shouning town }\end{array}$ & $\begin{array}{l}\text { resolve water } \\
\text { dispute }\end{array}$ & $\begin{array}{l}\text { across provincial } \\
\text { jurisdiction }\end{array}$ & permanent & $\begin{array}{l}\text { enterprise to } \\
\text { government }\end{array}$ \\
\hline 3 & 2006 & $\begin{array}{c}\text { Fuqing } \\
\text { Nuclear Power, } \\
\text { Sanshan Town }\end{array}$ & $\begin{array}{l}\text { solve water } \\
\text { demand }\end{array}$ & $\begin{array}{l}\text { under municipal } \\
\text { jurisdiction }\end{array}$ & permanent & $\begin{array}{l}\text { enterprise to } \\
\text { government }\end{array}$ \\
\hline 4 & 2014 & $\begin{array}{l}\text { Quanzhou city, } \\
\text { Yongtai county }\end{array}$ & $\begin{array}{c}\text { resolve water } \\
\text { dispute }\end{array}$ & $\begin{array}{l}\text { across municipal } \\
\text { jurisdiction }\end{array}$ & permanent & $\begin{array}{l}\text { government to } \\
\text { government }\end{array}$ \\
\hline
\end{tabular}

However, due to the lack of relevant water rights management system guidance, the existing water rights trading cases had problems with non-standard trading process, which might easily affect the sustainability of the transaction.

\subsection{The Needs of Trading in Water-rich Areas}

\subsubsection{Mitigate the Water Shortage in the Regional Economic Development}

The total amount of water available in water-rich areas was abundant, but there were still regional water shortage problems caused by uneven spatial and temporal distribution of water resources and different levels of regional water efficiency. For example, the per capita water resource occupancy in Yiwu city was lower than the average level in China, which led to water shortage as a key constraint factor limiting its sustainable economic development. This was related to the high-water consumption of production in regional economic development. The adjacent 
Dongyang city had abundant water resources and was equipped with a comprehensive water-related infrastructure. However, it was limited by the slow level of economic development and could not leverage effectively the advantages of its water resources. To coordinate regional economic development, the two places had carried out water diversion plans and administrative coordination plans under the coordination of the top government officials, but it was difficult to form a sustainable water use mechanism. In this situation, the two places took the lead in China to explore the introduction of a market mechanism and use water rights transaction to achieve a mutually beneficial regional arrangement and solve the regional problem of water shortage or financial shortage. Through water rights transfer, Yiwu city solved the water demand for sustainable economic development and Dongyang city obtained financial funds to promote economic development. These solutions were driven by the motivation to conduct water trading in water-rich areas, optimize the allocation of water resources and solve the problem of water shortage for regional economic development.

\subsubsection{Solving the Water Demand of Large-scale New Projects}

With the acceleration of urbanization, the demand for energy and resources was increasing in water-rich regions undergoing rapid economic development. The local government had to accelerate the approval of new large-scale enterprises, including thermal power enterprises and nuclear power enterprises that consumed large amounts of water. In the situation of insufficient supply of local water resources and high investment costs related to construction of diversion projects, it would be economical and effective if the large new projects obtained allocation share of local water in the market through water rights transactions and guaranteed the water demand of enterprises. Fuqing Nuclear Power obtained the permanent rights of water resource use and management by purchasing the Beilin reservoir, which fulfilled the enterprise's requirements for the reserve water resources. This is undoubtedly a typical case of utilizing water trading to solve the water demand of new enterprises, and it also provided a reference to expand the market size of water right transactions and optimize the allocation of water resources in water-rich regions.

\subsubsection{Coordinating Trans-jurisdiction Water Disputes}

In the shortage of available water resources, the development of water resources in the border regions becomes an inevitable choice, which is also likely to cause water disputes across the jurisdiction areas. Although the system and mechanism construction of China's water rights market is improving day by day, the water dispute involving cross-administrative jurisdiction is still a sensitive and complicated problem. The single administrative coordination mode adopted in China's planned economy period was more and more difficult to adapt to the economic development requirements under the new market situation. In water disputes across provincial-level jurisdiction areas, the resolution of water rights trading could optimize the allocation of water resources in the basin and improve the utilization rate of water resources. Moreover, it could effectively alleviate upstream and downstream water-related conflicts and improve regional social welfare. For example, the smooth resolution of inter-provincial water disputes in Dayankeng Hydropower Station in Qingyuan country fully demonstrated that the market mechanism could be used to coordinate the interest demands of all parties involved in water disputes across jurisdictions, provide a win-win situation for both parties, and become a new choice for water resource management in the new era.

\subsection{The Difficulties of Conducting Trading in Water-rich Areas}

\subsubsection{Lack of Understanding of Trading Benefits}

Through field research and interviews, we found that the implementation of regional industrial structure optimization and upgrades in China improved the utilization efficiency of water resources in the Taihu Basin; additionally, the total water consumption in the basin had shown a steady but decreasing trend. Besides the rapid growth of water consumption in the service industry, the total amount of industrial water had declined and the agricultural water consumption decreased year over year with the decrease of the agricultural irrigation area. At the same time, the actual total water consumption of the Taihu Basin and the regional water consumption indicators specified by China's most stringent water resource management system still had a large amount of 
savings, such as 2.98 billion $\mathrm{m}^{3}$ of surplus water in Jiangsu province and 4.71 billion $\mathrm{m}^{3}$ of surplus water in Shanghai in $2015^{[14]}$.

Therefore, in the case of a large surplus of regional total water consumption indicators, the inherent power of water rights trading in water-rich regions was insufficient, and the water rights owners' understanding of water rights trading was relatively weak. Among them, individuals or enterprises with water access rights could apply for water access right index for free, so it was difficult to generate consciousness of adjusting water share in the market through water access rights transaction. Under the circumstances of dispersing irrigation water and imperfect irrigation measurement facilities, it was challenging for irrigation water users to learn how to obtain additional benefits through water rights trading ${ }^{[17-18]}$. However, as regional economic development demands more and more water resources, inter-governmental regional water rights trading is increasing. However, due to the lack of understanding of regional water rights trading planning, water resources demonstration and transaction supervision, the coordination cost of regional water rights trading was high and the efficiency was low.

\subsubsection{The Irregular Process of Trading}

According to the interim measures on the administration of water rights trading issued by the Ministry of Water Resources of China, the core elements of water rights trading included transaction subject, transaction mode, transaction volume, transaction price, transaction period, and transaction supervision. In the previous cases, the transaction subject, transaction mode, and transaction volume of the water right trade were clear, but many administrative interventions and irregularities were still in the way as well as the process of determining such elements as the water right trade price and the water right trade term. To begin with, the price of water rights transaction was the compensation cost resulting from negotiations among various parties rather than the transaction price based on the water market price mechanism, which could not effectively reflect the real value of water rights ${ }^{[19-20]}$. Secondly, the maturity of water rights trading was not standard. Most of the world's water rights trade was temporary, while permanent water rights trade was rare. However, the duration of the transaction in the case had the nature of permanent water rights transaction, which made it difficult to adjust the water rights of the transaction, thus laying a hidden danger for the sustainability of the transaction. Finally, the transaction agreement was short of provisions on water rights transaction demonstration, transaction process supervision, and third-party interest compensation, which was likely to cause subsequent water rights transaction disputes. For example, in the case of Fuqing Nuclear Power, there was not a clear form about the water charges on the residents and enterprises for business in the vicinity, resulting in a farm encroaching on nearly 2 million yuan of the enterprises' profits.

\subsubsection{Excessive Administrative Intervention}

The cases of water rights transaction in the Taihu Basin demonstrate that whether it was to regulate water shortage in regional economic development or to solve the water demand of large new projects, it was the result of active organization and coordination by the top government institutions. It usually took a long time for the two parties to form an effective water rights trading agreement, which failed to provide for the regulating effect of the market mechanism on the use of water resources. For example, it took more than 10 years for Dongyang city and Yiwu city to form China's first water rights transaction, and it took three years for the trans-basin water transfer of Dayankeng Hydropower Station to be solved.

However, administrative coordination was also an effective guarantee for the formation of water rights transactions. Introducing the market mechanism into the water rights market, reducing the government's administrative intervention, and stimulating the vitality of the water market were still difficult problems. On the one hand, the water market was not a complete free market, but a quasi-market with some characteristics of public products, which could not be regulated completely by the market mechanism. On the other hand, administrative coordination was still the main way of water rights transaction because there were few existing participants in the water market in the areas. 


\subsubsection{The Imperfection of Trading Institution}

China's Ministry of Water Resources had issued a series of normative documents and departmental regulations on water rights trading, but compared with the mature water rights market, there were still imperfections ${ }^{[21]}$. The existing water rights trading system lacked regulations on the interests of third parties, and it was difficult to effectively protect the interests of third parties, which might affect the sustainability of water rights trading and reduce the utility of water rights trading. For example, the water rights trade between Dongyang city and Yiwu city did not consider the third-party influence, and there was no compensation scheme for the residents in the reservoir area, which led to local farmers' negative feelings about the water rights trade. Therefore, the water-rich region needed to further explore the water-right trading mechanism that had a small scale, covered a scattered area, and involved many stakeholders.

Author Contributions: F.W. and M.Z. proposed the research ideas and methods of the manuscript and were responsible for data collection and writing. S.L., J.S., X.X., F.L. and W. Y put forward revision suggestions for the paper.

Funding: The study is supported by the National Natural Science Foundation of China (No. 71774048) and Key project of philosophy and social science in Jiangsu University (No. 2018SJZDI048).

Conflicts of Interest: The authors declare no conflict of interest.

\section{References}

1. Bekchanov, M.; Bhaduri, A.; Ringler, C. Potential gains from water rights trading in the Aral Sea Basin. Agric. Water Manage.2015,152,41-56.

2. Garrick, D.; Whitten, S.M.; Coggan, A. Understanding the evolution and performance of water markets and allocation policy: a transaction costs analysis framework. J. Ecol. Econ. 2013, 88, 195-205.

3. Hearne, R.R.; Easter, K.W. The economic and financial gains from water markets in Chile. J. Agricultural Economics. 1997, 15, 187-199.

4. Wu, FP; Yu, QW; Shen, JY; Zhang, LN. Study on the theoretical framework of market-oriented water rights transaction price formation mechanism. J. China population, resources and environment, 2008,28(07):17-25. (in Chinese)

5. Shen, D.; Wu, J. State of the art review: water pricing reform in China. Int. J. Water Resour. Dev. 2016, 33 (2), 1-36.

6. Ge, M; Wu, F P; Chen, X P. A Coupled Allocation for Regional Initial Water Rights in Dalinghe Basin, China. J. Sustainability, 2017, 9(3):428.

7. Goetz, R.; Martinez, Y.; Rodrigo, J. Water allocation by social choice rules: the case of sequential rules. J. Ecol. Econ. 2008, 65, 304-314.

8. Wang, YH; Shu, QF; Wu, JZ. Review of water rights market research and prospect of water rights market research with Chinese characteristics. J. China population, resources and environment, 2007,27(06):87-100. (in Chinese)

9. Chen, Y.; Zhang, D.; Sun, Y.; Liu, X.; Wang, N.; Savenije, H.H.G. Water demand management: a case study of the Heihe River Basin in China. J. Physics and Chemistry of the Earth. 2005, 30, 408-419.

10. Liu, G; Yang, L, Shi, YB; Fang, Z; Wang, S. Empirical study on two-layer dynamic game pricing mechanism of water rights trading under quasi-market conditions. J. China population, resources and environment. 2012,27(04):151-159. (in Chinese)

11. Tian GL. Practical predicament of water rights system reform in the water-rich region of south China and countermeasures. J. Research on water conservancy development. 2017,17(12):8-12. (in Chinese) 
12. Guan, DB; Klaus, H. Assessment of Regional Trade and Virtual Water Flows in China. J. Ecological Economics, 2007, 61(1).

13. Faye, D, Carlos LM. Do Water-Rich Regions Have a Comparative Advantage in Food Production? Improving the Representation of Water for Agriculture in Economic Models. J. Economic Systems Research, 2012, 24(4):371-389.

14. Taihu basin and Southeast Rivers water resources bulletin 2016. Z. Shanghai: taihu basin bureau of the ministry of water resources, 2017.

Available online: http://www.tba.gov.cn/contents/44/14717.html

15. Shen, MH. Water rights trade and government innovation-a case study of the water rights trade case in yiwu, dongyang. J. Management world,2005(06):45-56. (in Chinese)

16. Hu, Z.;Chen, Y.; Yao, L.; Wei, C.; Li, C. Optimal allocation of regional water resources:

from a perspective of equity-efficiency tradeoff. J. Resour. Conserv. Recycl. 2016,109, 102-113.

17. Yoo, J.; Simonit, S.; Connors, J.P.; Maliszewski, P.J.; Kinzig, A.P.; Perrings, C. The value of agricultural water rights in agricultural properties in the path of development. J. Ecol. Econ. 2013, 91, 57-68.

18. Sharma, P.; Sharma, R.C. Factors determining farmers' decision for buying irrigation water: study of groundwater markets in Rajasthan. J. Agricultural Economics

Research Review. 2006, 19, 39-56.

19. Crase, L.; O'Keefe, S.; Dollery, B. Talk is cheap, or is it? The cost of consulting about uncertain reallocation of water in the Murray-Darling Basin Australia. J. Ecol. Econ. 2013, 88, 206-213.

20. Hellegers, P.J.G.J.; Perry, C.J. Can Irrigation water use be guided by market forces? Theory and practice. J. Water Resources Development. 2006, 22, 79-86.

21. Rivera, D.; Godoy-Faundez, A.; Lillo, M.; Alvez, A.; Delgado, V.; Gonzalo-Martin, C.;

Menasalvas, E.; Costumero, R.; Garcia-Pedrero, A. Legal disputes as a proxy for regional conflicts over water rights in Chile. J. Hydro. 2016, 535, 36-45. 